\title{
Effect of Zanthoxylum alkylamides on glucose metabolism in streptozotocin-induced diabetic Sprague-Dawley rats
}

Rui Wang ${ }^{1,2 \dagger}$, Yu-ming You ${ }^{3 \dagger}$ and Xiong Liu ${ }^{1^{*}}$ (D)

\begin{abstract}
This research aimed at investigating the hypoglycemic effect of Zanthoxylum alkylamides and whether TRPV1 receptor could participate in the glucose metabolism by using streptozotocin-induced diabetic rat model. The results showed that the blood glucose measured in the Zanthoxylum alkylamides treated group (ALK) showed significantly lower values than that in the model group (Model). Significant improvements in the oral glucose tolerance as well as plasma insulin and hepatic glycogen were also observed in the ALK group, when compared to the model group. However, the improving effects of Zanthoxylum alkylamides on glucose metabolism disorder in diabetic rats were markedly inhibited by capsazepine as the TRPV1 receptor antagonist. In addition, there were significant differences in the levels of mRNA and protein of phosphoenolpyruvate carboxylase (PEPCK), gucose-6-phosphatase (G6Pase), glucokinase (GK) and cannabinoid receptor I (CB1) in the livers of the ALK group compared to model group. Meanwhile, ALK group also exhibited a remarkable increase in the pancreatic-duodenal homeobox 1 (PDX-1), glucose transporter 2 (GLUT 2), GK levels and a significant decrease in the expression levels of CB1 in the pancreas, while the presence of capsazepine would affected the expression of these genes. These findings indicate that Zanthoxylum alkylamides could ameliorate the glucose metabolism disorder in diabetic rats. Furthermore, the TRPV1 receptor could participate in regulating the expressions of genes and proteins related to glucose metabolism and insulin secretion in the liver and pancreas, and takes a role in the hypoglycemic process of Zanthoxylum alkylamides.
\end{abstract}

Keywords: Zanthoxylum alkylamides, Diabetes, Glucose metabolism, TRPV1 receptor

\section{Introduction}

Transient Receptor Potential Vanilloid subtype 1 (TRPV1), also called capsaicin receptor, is a kind of non-selective cation channel with six trans-membrane domains. It can be activated by various physical and chemical factors such as weak acid $(\mathrm{pH}<5.9)$, noxious thermal stimulation $\left(>42{ }^{\circ} \mathrm{C}\right)$ and capsaicin, thus

*Correspondence: liuxiong848@hotmail.com

${ }^{\dagger}$ Rui Wang and Yu-ming You contributed equally to this work

${ }^{1}$ College of Food Science, Southwest University, Chongqing 400715,

China

Full list of author information is available at the end of the article mediating the internal flow of cations, such as $\mathrm{Ca}^{2+}$, $\mathrm{Mg}^{2+}$ and $\mathrm{Na}^{+}$in cells. The internal flow of cation in cells increases, resulting in a series of biological effects [1-3]. A large number of studies have shown that TRPV1 was involved in the development of various diseases, so it was predicted to be a new target of drug therapy $[4,5]$. Activating TRPV1 could have many physiological effects, such as promoting the secretion of insulin, improving insulin resistance, repairing pancreatic function and regulating glucose metabolism, which can be canceled or significantly reduced by knockout TRPV1 receptor or adding TRPV1 receptor competitive antagonist such as capsazepine [6-10]. Therefore, it can be concluded that 
TRPV1 receptor is also closely related to the development of diabetes; it has hence gained focus.

Zanthoxylum L. (Rutaceae) is mainly distributed in the tropical and subtropical regions of Asia, America, Africa and Oceania. In Asia, this species is often found in the southern, southeastern and eastern parts [11-13]. Because of their special flavors and tingling properties, the fruits of Zanthoxylum L. are used as a spice added to food in some countries [14]. Meanwhile, it also has been used as a traditional Chinese medicinal material in China [15-17].The numb-taste components in Zanthoxylum L. are due to the Zanthoxylum alkylamides, which consistent of chains of unsaturated aliphatic acid amides. At present, more than 25 different alkylamides have been separated and identified, including $\alpha$-sanshool, $\beta$-sanshool, $\gamma$-sanshool, hydroxy- $\alpha$-sanshool and hydroxy- $\beta$-sanshool, etc., [18-21]. It has been reported that Zanthoxylum alkylamides have anti-inflammatory, analgesic [22], hypoglycemic [23] and anesthesia effects [24]. Moreover, these alkylamides can also adjust the gastrointestinal system [25], remove wrinkles [14], and ameliorate protein metabolism disorders [26].

Previous studies have shown that by inhibiting gluconeogenesis, Zanthoxylum alkylamides may reduce the output of liver sugar, repair the function of pancreatic $\beta$-cells and promote the secretion of insulin, thus improving the glucose metabolism disorder induced by streptozotocin (STZ) in diabetic rats. At the same time, with the dose of Zanthoxylum alkylamides increasing, the expression of TRPV1 mRNA and protein in pancreas and livers of rats significantly increased and showed a certain dose effect [23]. Therefore, whether Zanthoxylum alkylamides could activate TRPV1 receptor, and then regulate the secretion of insulin and the expression and activity of genes related to glucose metabolism in diabetic rats, thereby improving the glucose metabolism disorder in diabetic rats, remained to be confirmed.

The diabetic Sprague-Dawley (SD) rats induced by STZ were took as model in this research. The rats were intraperitoneal injection of capsazepine or given Zanthoxylum alkylamides by gavage, and cotreatment of Zanthoxylum alkylamides and capsazepine. By observing the influence of different treatments on the fasting plasma glucose, oral glucose tolerance, plasma insulin, glycogen in body and genes related to glucose metabolism and insulin secretion in rats, this research discussed the hypoglycemic effect of Zanthoxylum alkylamides and the role of TRPV1 receptor in the glucose metabolism.

\section{Materials and methods}

\section{Extraction of Zanthoxylum alkylamides}

The extraction of Zanthoxylum alkylamides (purity >97\%) was performed following the description of literature, has been isolated and identified in our previous research. As shown in Fig. 1, it is composed of hydroxy- $\alpha$-sanshool, hydroxy- $\beta$-sanshool and hydroxy- $\gamma$-sanshool [23], the contents are $2.64 \%, 40.26 \%$ and $57.09 \%$ respectively.

\section{Solution preparation}

An amount of $0.5 \mathrm{~g}$ capsazepine (Biochempartner Co., Ltd, Shanghai, China) was precisely weighed and dissolved in $50 \mathrm{~mL}$ solution containing $2 \%$ tween $80,2 \%$ ethanol and $96 \%$ saline, which were made into $10 \mathrm{mg} /$ $\mathrm{mL}$ capsazepine peritoneal injection [27]. Ultrasonic was used assist dissolution the capsazepine solution before injection.

Zanthoxylum alkylamides was blow-dried with nitrogen, precisely weighed and dissolved in edible soybean oil in order to get $3.0 \mathrm{mg} / \mathrm{mL}$ solution. Then, the solution was given to the rats by gavage according to the body/ weight ratio of $0.2 \mathrm{~mL} / 100 \mathrm{~g}$.

\section{Animal treatment}

Healthy, clean male SD rats were purchased from Chongqing Tengxin Bill Experimental Animals Ltd (animal production license number SCXK (Chongqing) 2012-0008).

Forty healthy male SD rats, weighing $160-200 \mathrm{~g}$ and 6-8 weeks old, were fed in a well-ventilated environment with room temperature of $23 \pm 2{ }^{\circ} \mathrm{C}$, relative humidity of $45-65 \%$ and $12 \mathrm{~h} / 12 \mathrm{~h}$ change between light, and they could eat and drink freely. After the rats were fed with basic fodder to adapt to the new environment for one week, the rats were made to fast for $12 \mathrm{~h}$. Eight rats were randomly selected by weight as the control group, and the rest were intraperitoneal injection of $60 \mathrm{mg} / \mathrm{kg}$ bw streptozotocin (Sigma-Aldrich Company, St. Louis, USA) solution, dissolved in $0.1 \mathrm{~mol} / \mathrm{L}$ citric acid buffer $(\mathrm{pH} 4.5)$ [7]. The normal control group was given the same dose of citric acid buffer. After the rats were injected with STZ solution for 3 days, they were made to fast for $12 \mathrm{~h}$, and blood was collected from the tail vein. The blood glucose value was determined by the glucometer. The rats whose blood glucose value was higher than $11.1 \mathrm{mmol} / \mathrm{L}$ were selected for experimental group division.

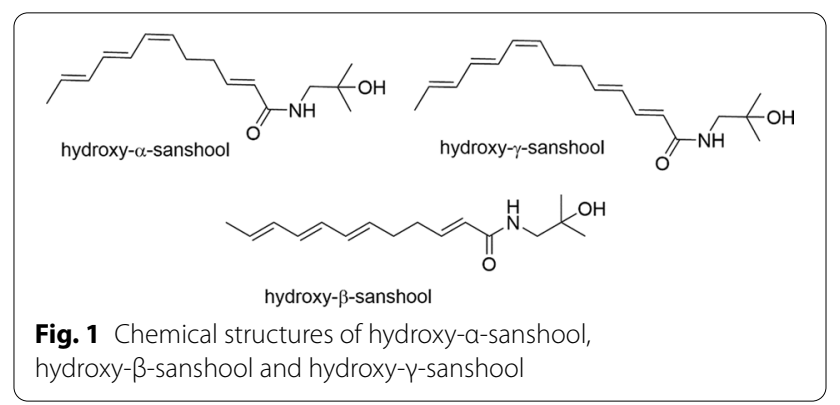


Eight rats were used as normal control group (Control), and thirty-two rats with successful modeling were divided into four groups according to their blood glucose value based on randomized block method, with eight rats in each group. The four groups were model group (Model), Zanthoxylum alkylamides group (ALK), capsazepine group (CAPZ), Zanthoxylum alkylamides and capsazepine group (ALK +CAPZ). Rats in the ALK group were given $6.0 \mathrm{mg} / \mathrm{kg}$ bw Zanthoxylum alkylamides solution by gavage and intraperitoneal injection of $1 \mathrm{~mL} /$ $\mathrm{kg}$ bw capsazepine solvent every day. Rats in CAPZ group were intraperitoneal injection of $10 \mathrm{mg} / \mathrm{kg}$ bw capsazepine solution [28] and given $2 \mathrm{~mL} / \mathrm{kg}$ bw soybean oil by gavage every day. Rats in ALK + CAPZ group were intraperitoneal injection of $10 \mathrm{mg} / \mathrm{kg}$ bw capsazepine solution and given $6.0 \mathrm{mg} / \mathrm{kg}$ bw Zanthoxylum alkylamides by gavage. The control group and the model group were respectively intraperitoneal injection of $1 \mathrm{~mL} / \mathrm{kg}$ bw capsazepine solvent, and given $2 \mathrm{~mL} / \mathrm{kg}$ bw soybean oil by gavage.

During the administration, all the rats were given basic fodder, and they ate and drank freely. The body weight of the rats was measured every 2 days to calculate their food intake every day. The experimental cycle was 28 days.

This research was approved by the Animal Ethics Committee of Southwest University, Chongqing, China.

\section{Sample preparation}

After they were given the drug for the last time, all the rats were made to fast for $12 \mathrm{~h}$ and were anesthetized with ether. Then the rats were beheaded to collect blood from the neck. The blood was put in blood-collecting vessels containing heparin sodium and centrifuged under the condition of $1500 \times g$ and $4{ }^{\circ} \mathrm{C}$ for $15 \mathrm{~min}$. The plasma was frozen in $-80{ }^{\circ} \mathrm{C}$ fridge for future use. After the blood collection was completed, the rats were quickly dissected and their liver, pancreas, kidney and other tissues were removed. Then the rats were cleaned with cold normal saline, and the surface water was absorbed with absorbent paper. The rats were weighed to calculate the organ indexes. About $100 \mathrm{mg}$ liver and pancreas were precisely weighed and placed into $2 \mathrm{~mL}$ microcentrifuge tubes without RNA enzyme, which were immediately frozen in liquid nitrogen and stored at $-80{ }^{\circ} \mathrm{C}$ for the determination of related genes and protein expression. Another $100 \mathrm{mg}$ liver and muscle were stored at $-20{ }^{\circ} \mathrm{C}$ for the determination of glycogen.

\section{Determination of fasting blood glucose, oral glucose tolerance, plasma fructosamine, plasma insulin and glycogen}

After administration on the 0,14 and 28 days, the rats were made to fast for $12 \mathrm{~h}$, and blood was collected from the tail vein to determine the fasting blood glucose by glucometer (Maccura Biotechnology Co., Ltd, Chengdu, China).

One day before the end of the experiment, the rats were made to fast for $12 \mathrm{~h}$ and then fed with $2.0 \mathrm{~g} / \mathrm{kg} \cdot \mathrm{bw}$ glucose solution by gavage, and blood samples were collected from the tail vein at $0,30,60,90$ and $120 \mathrm{~min}$ after the feeding. Blood glucose value was determined with glucometer, and the Area under the Curve (AUC) was calculated using Origin 8.1 software with the trapezoidal integral method.

The content of fructosamine in plasma was determined by fructosamine assay kit (Maccura Biotechnology Co., Ltd, Chengdu, China). Meanwhile, the content of plasma insulin was determined by Enzyme Linked Immunosorbent Assay Kit (Nanjing Jiancheng Bioengineering Institute, Nanjing, China). Moreover, the Glycogen was determined by glycogen test kit (Nanjing Jiancheng Bioengineering Institute, Nanjing, China).

\section{Quantitative PCR (qPCR) assay}

Total RNA in frozen liver and pancreas tissues was extracted using the total RNA extraction kit (Takara Biotechnology Co., Ltd, Dalian, China), and the extracted total RNA was diluted to an appropriate concentration. Then, $2 \mu \mathrm{L}$ diluted total RNA solution was taken out and reverse-transcribed using reverse transcription kit (Takara Biotechnology Co., Ltd, Dalian, China) to obtain cDNA template; $2.0 \mu \mathrm{L}$ cDNA template, $10.0 \mu \mathrm{L}$ SYBR Premix Ex TaqII $(2 \times), 1 \mu \mathrm{L}$ upstream and downstream primers (the gene primers were designed and synthesized by Shanghai Sangon Biotech Co., Ltd., the sequences are shown in Table 1) were mixed for pre-degeneration for

Table 1 Sequences of primers used in this study

\begin{tabular}{ll}
\hline Gene name & Sequence \\
\hline$\beta$-actin & Forward: ACGTCAGGTCATCACTATCG \\
& Reverse: GGCATAGAGGTCTTTACGGATG \\
CB1 & Forward: CTGAGGAGCAAGGACCTGAGAC \\
& Reverse: GTTGTTGGCGTGCTTGTGC \\
GK & Forward: GCTTTTGAGACCCGTTTCGT \\
& Reverse: CGCACAATGTCGCAGTCG \\
G6Pase & Forward: GGCTCACTTTCCCCATCAGGT \\
& Reverse: CCAAGTGCGAACCAAACAGG \\
PEPCK & Forward: GACAGACTCGCCCTATGTGGTG \\
& Reverse: GGTTGCAGGCCCAGTTGTTG \\
PDX-1 & Forward: AAACGCCACACACCAAGGAGAA \\
& Reverse: AGACCTGGCGTTCACATG \\
GLUT2 & Forward: CCAGCACATACGACACCAGACG \\
& Reverse: CCAAAGAACGAGGCACCAT \\
\hline
\end{tabular}


10 min under the condition of $95^{\circ} \mathrm{C}$ and degeneration for $10 \mathrm{~s}$ under the condition of $95^{\circ} \mathrm{C}$, annealing $20 \mathrm{~s}$ at $55^{\circ} \mathrm{C}$, and extending for $30 \mathrm{~s}$ at $72{ }^{\circ} \mathrm{C}$, and the whole reaction included 45 cycles. At the same time, high-resolution solution curve experiment was carried out. The relative expression level of each target gene was calculated by $2^{-\Delta \Delta \mathrm{Ct}}$ method, taking $\beta$-actin as the internal reference.

\section{Western blot analysis}

A total of $100 \mathrm{mg}$ liver and pancreas tissue samples were homogenized with $1 \mathrm{~mL}$ pre-cooled lysate, $5 \mu \mathrm{L}$ phosphatase inhibitor and $10 \mu \mathrm{L}$ PMSF and centrifuged at $16,100 \times g, 4{ }^{\circ} \mathrm{C}$ for $10 \mathrm{~min}$. The supernatant was separated and stored at $-80{ }^{\circ} \mathrm{C}$. BCA protein assay kit (Sangon Biotech Co., Ltd, Shanghai, China) was used for the quantification of proteins. After the samples of each group were diluted to an appropriate concentration, the diluted protein solution was mixed with Sample Buffer at 1:1 and then heated for $5 \mathrm{~min}$ at $100{ }^{\circ} \mathrm{C}$. Then distilled water, 30\% Acrylamide-Bisacrylamide, separation gel Buffer, concentration gel Buffer, 10\% Ammonium persulfate and Tetramethyldiethylamine were mixed proportionately into Sodium dodecyl sulfate polycrylamide gel electrophoresis (SDS-PAGE) resolving gel and stacking gel (Beyotime Biotechnology Institute, Shanghai, China), and then infused into slab for future use.

Prestained Protein Ladder (Thermo Fisher Scientific Inc., Shanghai, China) and the samples were individually spotted into the sample holes of the slab. Then SDSPAGE gel containing protein was subjected to $20-40 \mathrm{~min}$ vertical gel electrophoresis according to the molecular weight of the target protein. Polyvinylidene fluoride (PVDF) membrane was activated by methanol for $5 \mathrm{~min}$, then transfer the protein to PVDF membranes. After that, the PVDF membrane was washed by $0.01 \mathrm{~mol} / \mathrm{L}$ Tris Buffered Saline with Tween 20 (TBST). Then the non-specific binding on the membrane was closed with sealing liquid, and the mixture was shaken for about $1.5 \mathrm{~h}$ in the shaking bed at $37^{\circ} \mathrm{C}$.

After sealing, the first antibody was shaken for about $1.5 \mathrm{~h}$ in the shaking bed at $37^{\circ} \mathrm{C}$ and washed with $0.01 \mathrm{~mol} / \mathrm{L}$ TBST solution. The second antibody labeled with horseradish peroxidase was shaken for about $1.5 \mathrm{~h}$ in the shaking bed at $37{ }^{\circ} \mathrm{C}$ and washed with $0.01 \mathrm{~mol} / \mathrm{L}$ TBST solution. The antibodies of $\beta$-actin, CB1, PEPCK, GK, GLUT 2 and PDX-1 were purchased from Abcam Co., Ltd (Cambridge, UK). The antibody of G6Pase was purchased from Santa Cruz Biotechnology, Inc. (Texas, USA).

MILLIPORE chemiluminescence reagents $\mathrm{A}$ and $\mathrm{B}$ in equal volume were evenly mixed and then sprayed on PVDF membrane for reaction for $5 \mathrm{~min}$, and then placed in Gel Doc XR+ for observation. The bands were analyzed using Image $1.44 \mathrm{p}$ software to get the grayscale value of the target band. Then divided the grayscale value of the target protein by the grayscale value of the internal parameter to get the result. Finally, set the result of control group to 1, divided the calculation results of other groups by the results of the control group, and performed normalization processing getting the final calculation results.

\section{Data statistics and analysis}

The results were expressed as mean \pm standard deviation. One-way ANOVA was performed to analyze the data by GraphPad Prism 7.04. The differences among groups were evaluated by Tukey's multiple comparisons test. A value of $\mathrm{P}<0.05$ was considered significant. Origin 8.5 was used for data plotting.

\section{Results \\ Effect of TRPV1 receptor antagonist and Zanthoxylum alkylamides on body weight and food intake}

One week after intraperitoneal injection of STZ, fasting blood glucose value of the rats was measured. If the blood glucose value was higher than $11.1 \mathrm{mmol} / \mathrm{L}$, the rats were considered as successful in modeling. The rats moved less, and their hair was fluffy and dull. They also showed some typical diabetes symptoms such as polyphagia and polyuria. As shown in Fig. 2, compared with the control group, the weight gain of the model group significantly decreased, whereas the food intake significantly increased $(\mathrm{P}<0.05)$. Compared with the model group, the weight gain and food intake of rats in ALK group significantly changed $(\mathrm{P}<0.05)$. However, the CAPZ group and the ALK + CAPZ group showed no significant difference on the weight gain of the rats $(P>0.05)$. Compared with the ALK group, the weight gain of CAPZ group and ALK + CAPZ group decreased by $47.75 \%$ and $36.15 \%$ respectively $(\mathrm{P}<0.05)$.

\section{Effect of TRPV1 receptor antagonist and Zanthoxylum alkylamides on organ indexes}

The effects of TRPV1 receptor antagonist and Zanthoxylum alkylamides on organ indexes in diabetic rats are shown in Table 2. Compared with the control group, the liver and kidney indexes in the model group significantly increased $(P<0.05)$, whereas the pancreas index had no significant difference $(P>0.05)$. Compared with the model group, the liver and kidney indexed in rats of CAPZ and ALK + CAPZ groups showed no significant difference $(P>0.05)$, whereas the ALK group, the liver and kidney indexes of rats decreased significantly 

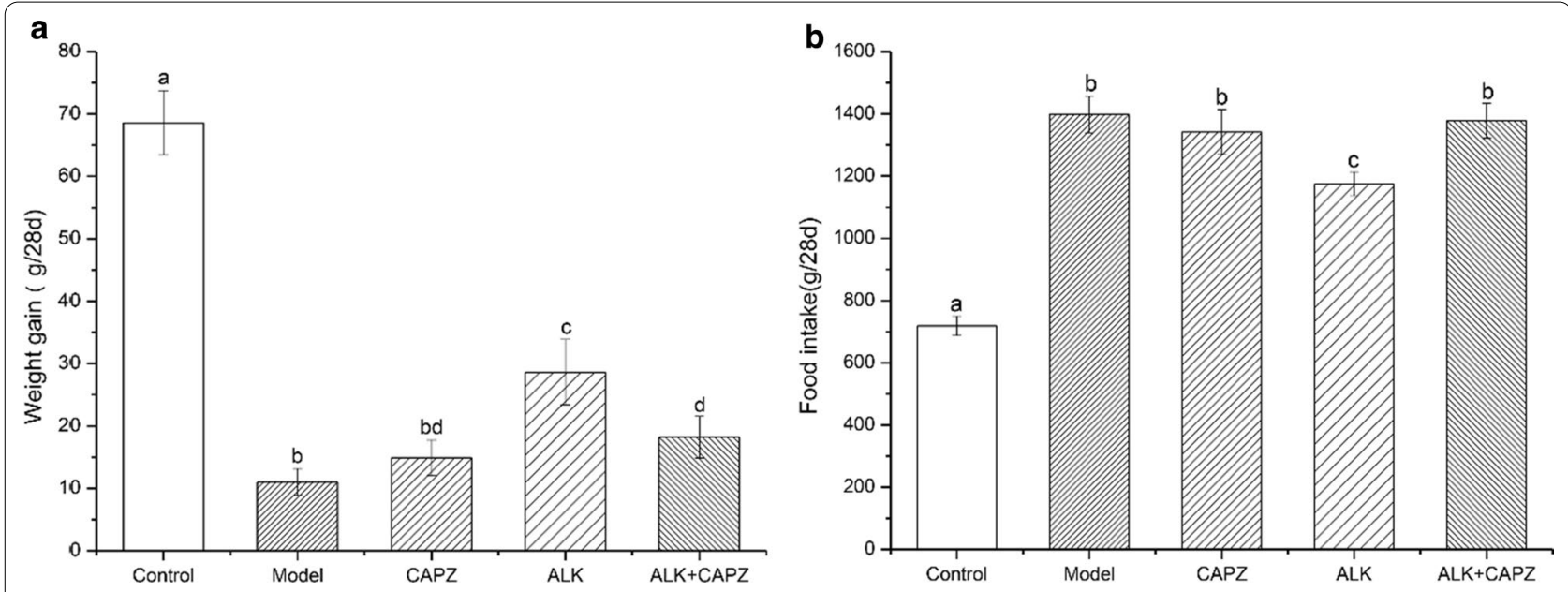

Fig. 2 Effect of TRPV1 receptor antagonist and Zanthoxylum alkylamides on body weight and food intake in diabetic rats. a Body weight gain; b food intake. For each group, $n=8$ rats. ${ }^{a-d}$ Mean values with different letters are significant difference $(p<0.05)$ according to Tukey's multiple comparisons test

Table 2 Effect of TRPV1 receptor antagonist and Zanthoxylum alkylamides on organ index in diabetic rats

\begin{tabular}{llll}
\hline & Liver & Kindey & Pancreas \\
\hline Control & $3.18 \pm 0.15^{\mathrm{a}}$ & $0.71 \pm 0.05^{\mathrm{a}}$ & $0.24 \pm 0.07^{\mathrm{a}}$ \\
Model & $3.93 \pm 0.10^{\mathrm{b}}$ & $1.06 \pm 0.06^{\mathrm{b}}$ & $0.28 \pm 0.02^{\mathrm{ab}}$ \\
CAPZ & $4.09 \pm 0.23^{\mathrm{b}}$ & $1.13 \pm 0.06^{\mathrm{b}}$ & $0.27 \pm 0.03^{\mathrm{ab}}$ \\
ALK & $3.52 \pm 0.14^{\mathrm{a}}$ & $0.96 \pm 0.02^{\mathrm{c}}$ & $0.30 \pm 0.03^{\mathrm{b}}$ \\
ALK + CAPZ & $3.92 \pm 0.50^{\mathrm{b}}$ & $1.09 \pm 0.08^{\mathrm{b}}$ & $0.28 \pm 0.01^{\mathrm{ab}}$ \\
\hline
\end{tabular}

For each group, $\mathrm{n}=8$ rats

a-c Mean values with different letters in the same column are significant difference $(p<0.05)$ according to Tukey's multiple comparisons test

$(\mathrm{P}<0.05)$. In addition, the effects of all treatments on pancreas index of rats were not significant $(P>0.05)$.

\section{Effect of TRPV1 receptor antagonist and Zanthoxylum alkylamides on fasting blood glucose level}

As can be seen from Fig. 3, throughout the experiment, the fasting blood glucose levels of rats in the control group remained within the normal range, whereas the fasting blood glucose levels of rats in the diabetes groups were higher than $11.1 \mathrm{mmol} / \mathrm{L}$, which were significantly higher than that of the control group $(\mathrm{P}<0.05)$, indicating that the modeling was successful and relatively stable. After the diabetic rats with similar initial fasting blood glucose levels were given different administration after $28 \mathrm{~d}$, the fasting blood glucose levels of rats in each group had changed. Compared with the model group, the CAPZ group and the ALK + CAPZ group had no significant differences on the fasting blood glucose levels of rats $(P>0.05)$, and the fasting blood glucose level of the ALK

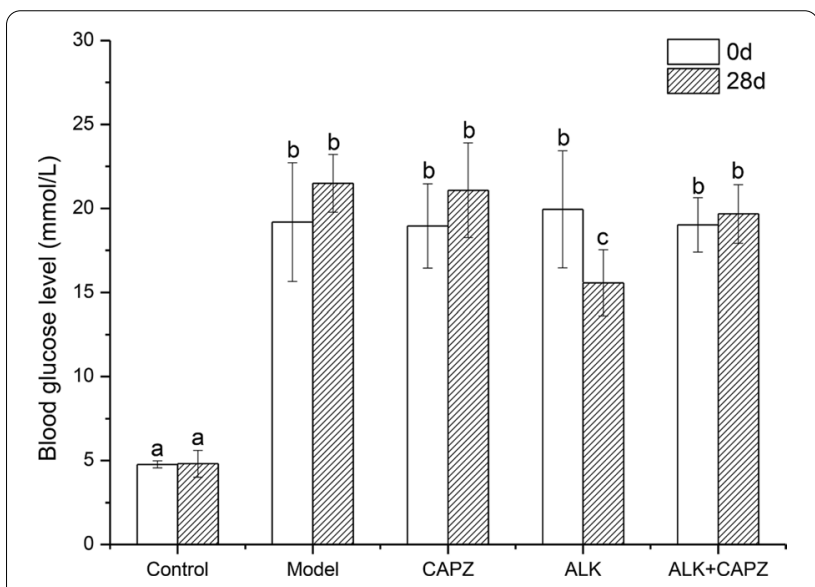

Fig. 3 Effect of TRPV1 receptor antagonist and Zanthoxylum alkylamides on fasting blood glucose level in diabetic rats. For each group, $n=8$ rats. ${ }^{a-c}$ Mean values with different letters are significant difference $(p<0.05)$ according to Tukey's multiple comparisons test

group decreased by $27.43 \%(\mathrm{P}<0.05)$, which was significantly lower than the CAPZ group and the ALK + CAPZ group $(\mathrm{P}<0.05)$.

\section{Effect of TRPV1 receptor antagonist and Zanthoxylum alkylamides on oral glucose tolerance}

As shown in Fig. 4, at the end of the experiment, after the rats took $2.0 \mathrm{~g} / \mathrm{kg}$.bw glucose orally, their oral glucose tolerance had changed. After rats in the control group took glucose solution orally for $30 \mathrm{~min}$, their blood glucose level reached the highest, then fell fast and returned to the original level at $120 \mathrm{~min}$. However, after the rats took glucose orally, the blood glucose level of diabetes model 

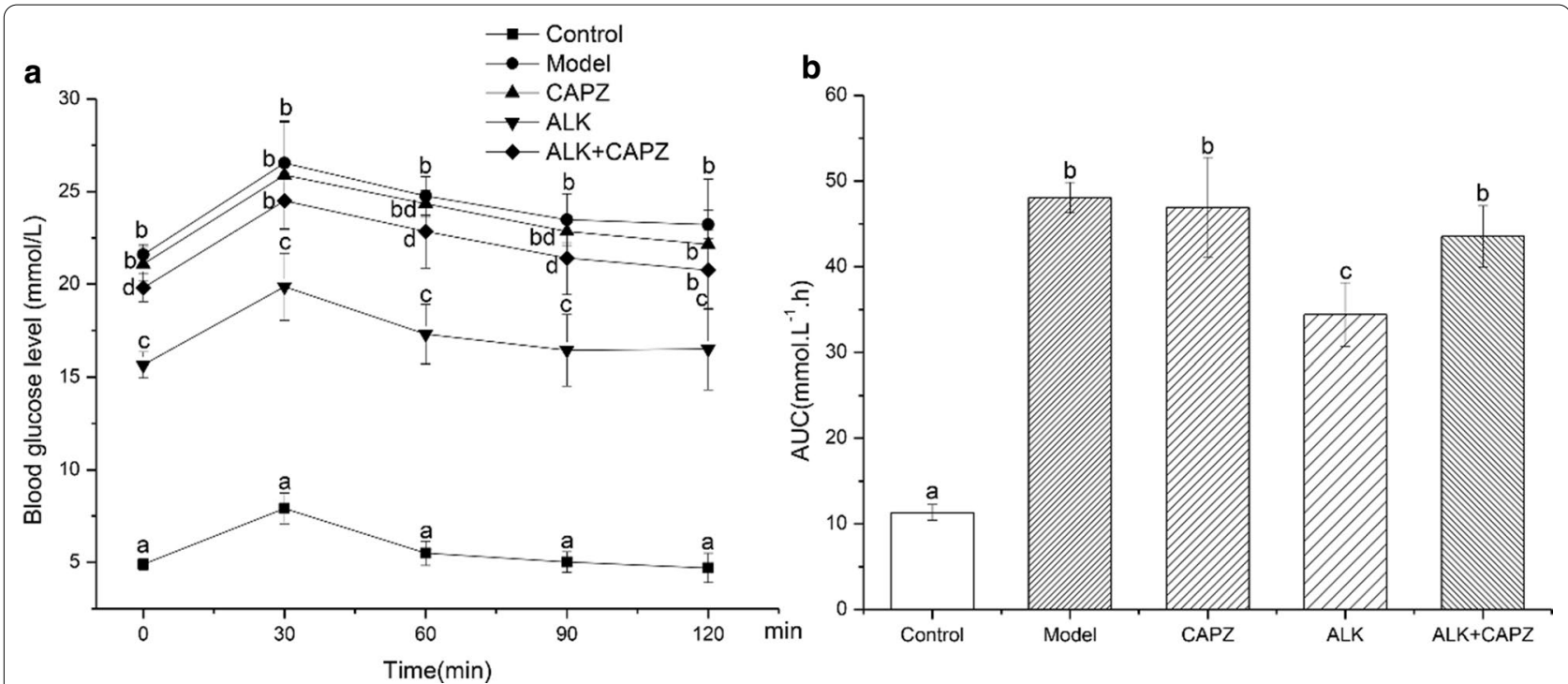

Fig. 4 Effect of TRPV1 receptor antagonist and Zanthoxylum alkylamides on oral glucose tolerance in diabetic rats. a Blood glucose level; b area under oral glucose tolerance curve. For each group, $n=8$ rats. ${ }^{a-d}$ Mean values with different letters are significant difference $(p<0.05)$ according to Tukey's multiple comparisons test

rats also reached the highest at $30 \mathrm{~min}$, but it decreased slowly and still stayed at a rather high level at $120 \mathrm{~min}$. Compared with the control group, the area under the oral glucose tolerance curve of the diabetic model group significantly increased by $317.25 \%(\mathrm{P}<0.05)$. Compared with the model group, the blood glucose levels of rats in all the administration groups reached the highest at 30 min after the rats took glucose orally, but the blood glucose levels of rats in CAPZ and ALK + CAPZ groups decreased slowly and also stayed at a rather high level at $120 \mathrm{~min}$, and the area under oral glucose tolerance curve showed no significant difference $(P>0.05)$. However, the blood glucose levels of rats in the ALK group fell faster, improving the oral glucose tolerance of rats, and the area under oral glucose tolerance curve significantly decreased by $28.23 \%(\mathrm{P}<0.05)$, but the value was yet to return to the original level at $120 \mathrm{~min}$.

\section{Effect of TRPV1 Receptor Antagonist and Zanthoxylum alkylamides on plasma Fructosamine level}

The effects of TRPV1 receptor antagonist and Zanthoxylum alkylamides on plasma fructosamine level in diabetic rats are showed in Fig. 5. Compared with the control group, plasma fructosamine level in the model group increased significantly by $33.15 \%(\mathrm{P}<0.05)$. After the rats were administrated for 28 days, as compared to the model group, plasma fructosamine level of rats in the CAPZ group decreased to some extent, but not significantly, and the plasma fructosamine level in rats of

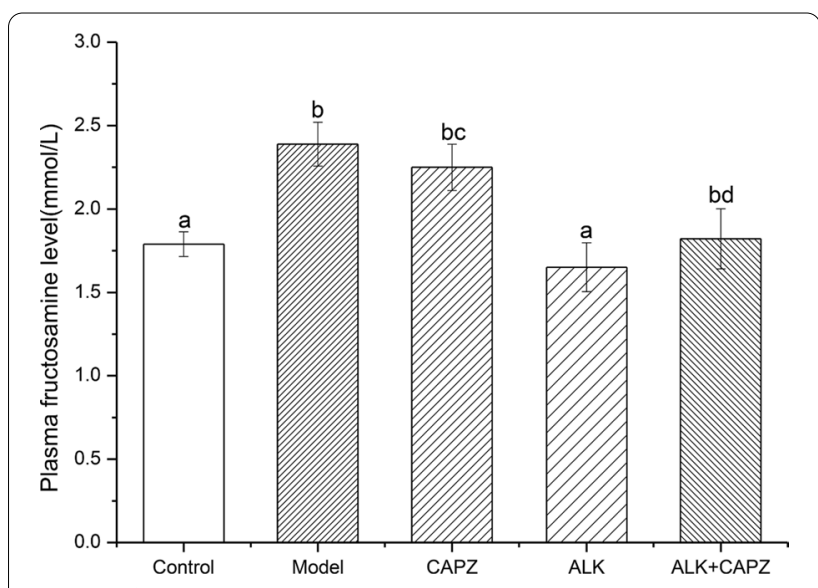

Fig. 5 Effect of TRPV1 receptor antagonist and Zanthoxylum alkylamides on plasma fructosamine level in diabetic rats. For each group, $n=8$ rats. ${ }^{a-d}$ Mean values with different letters are significant difference ( $p<0.05$ ) according to Tukey's multiple comparisons test

ALK and ALK + CAPZ groups decreased by $30.38 \%$ and $23.21 \%$ respectively $(\mathrm{P}<0.05)$. Plasma fructosamine level of the ALK group was significantly lower than the CAPZ group and the ALK + CAPZ group $(\mathrm{P}<0.05)$.

\section{Effect of TRPV1 receptor antagonist and Zanthoxylum alkylamides on plasma insulin}

Compared with the control group, plasma insulin levels in rats of the model group decreased by $27.38 \%(\mathrm{P}<0.05)$ as shown in Fig. 6. After the rats were administrated 


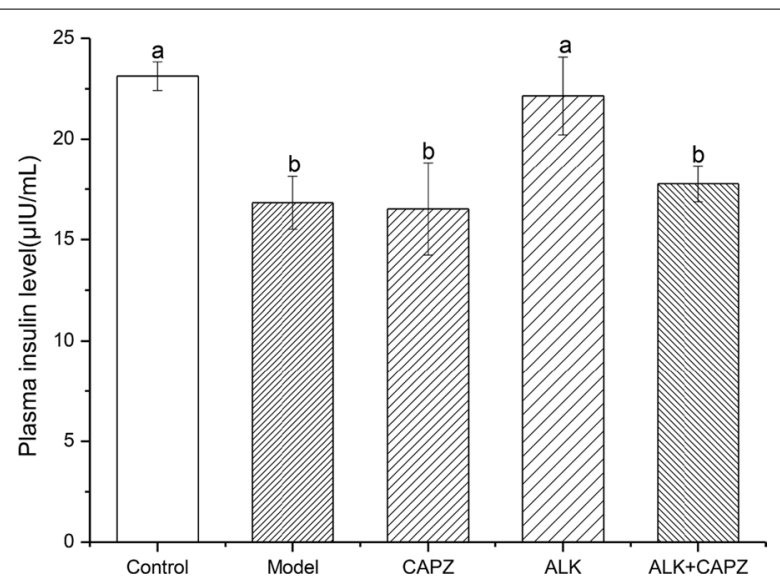

Fig. 6 Effect of TRPV1 receptor antagonist and Zanthoxylum alkylamides on plasma insulin in diabetic rats. For each group, $\mathrm{n}=8$ rats. ${ }^{a-b}$ Mean values with different letters are significant difference $(p<0.05)$ according to Tukey's multiple comparisons test

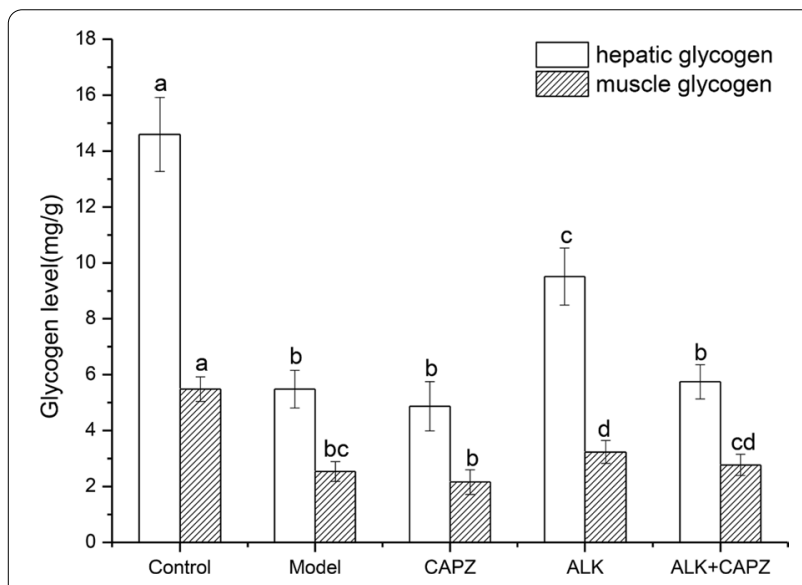

Fig. 7 Effect of TRPV1 receptor antagonist and Zanthoxylum alkylamides on hepatic glycogen and muscle glycogen in diabetic rats. For each group, $n=8$ rats. ${ }^{a-d}$ Mean values with different letters are significant difference $(p<0.05)$ according to Tukey's multiple comparisons test

for 28 days, the content of plasma insulin levels among groups showed differences. Compared with the model group, plasma insulin levels of the ALK group and the Alk + CAPZ group significantly increased by $32.94 \%$ and 6.31\% $(\mathrm{P}<0.05)$, whereas the CAPZ group had no significant difference $(P>0.05)$. Compared with the ALK group, plasma insulin of rats in CAPZ and ALK + CAPZ groups decreased significantly by $25.45 \%$ and $20.03 \%$ respectively $(\mathrm{P}<0.05)$.
Effect of TRPV1 receptor antagonist and Zanthoxylum alkylamides on hepatic glycogen and muscle glycogen According to Fig. 7, compared with the control group, the content of hepatic glycogen and muscle glycogen in the model group decreased significantly by $62.28 \%$ and $53.56 \%$ respectively $(\mathrm{P}<0.05)$. After the rats were administrated for 28 days, the content of hepatic glycogen and muscle glycogen in rats among groups had changed. Compared with the model group, the hepatic glycogen level of CAPZ group and ALK + CAPZ group had no significant differences, whereas the hepatic glycogen level of ALK group increased significantly by $73.22 \%(\mathrm{P}<0.05)$. While compared with the model group, the muscle glycogen levels of CAPZ group and ALK + CAPZ group had no significant differences, whereas the muscle glycogen level of ALK group increased by $23.68 \%$.

\section{The effects on the expression of liver glucose metabolism related genes and protein}

The effects of TRPV1 receptor antagonist and Zanthoxylum alkylamides on the expression of GK mRNA and protein in the liver of diabetic rats are shown in Fig. 8. Compared with the control group, the relative mRNA expression of GK in the liver of the model group significantly decreased by $77.87 \%$, and the expression of protein decreased by $51.44 \%(\mathrm{P}<0.05)$. Compared with the model group, after the rats were given Zanthoxylum alkylamides by gavage, the relative mRNA expression and protein level of GK in the liver of rats significantly increased by $170.37 \%$ and $28.30 \%(\mathrm{P}<0.05)$. Compared with the model group, the relative mRNA expression of GK in CAPZ group and ALK + CAPZ group no significant differences. Moreover, the relative protein level of GK in CAPZ group had no significant difference, whereas the relative protein level of GK in ALK + CAPZ group had significant difference. Compared with the ALK group, the relative mRNA expression of GK in liver of CAPZ and ALK + CAPZ groups decreased by $63.13 \%$ and $57.53 \%$ respectively, and the expression of protein decreased by $21.59 \%$ and $36.89 \%$ respectively $(\mathrm{P}<0.05)$.

As is shown in Fig. 8, the level of PEPCK mRNA and protein in the liver of the model group increased significantly $(\mathrm{P}<0.05)$, and their expression increased by $161.82 \%$ and $81.80 \%$ respectively compared with the control group. Compared with the model group, the expression of PEPCK in CAPZ group had no significant difference, whereas the expression of PEPCK in the ALK group and the ALK + CAPZ group decreased. The expression of PEPCK $\mathrm{mRNA}$ and protein in the rat liver of ALK group decreased by $38.54 \%$ and $38.83 \%$ 


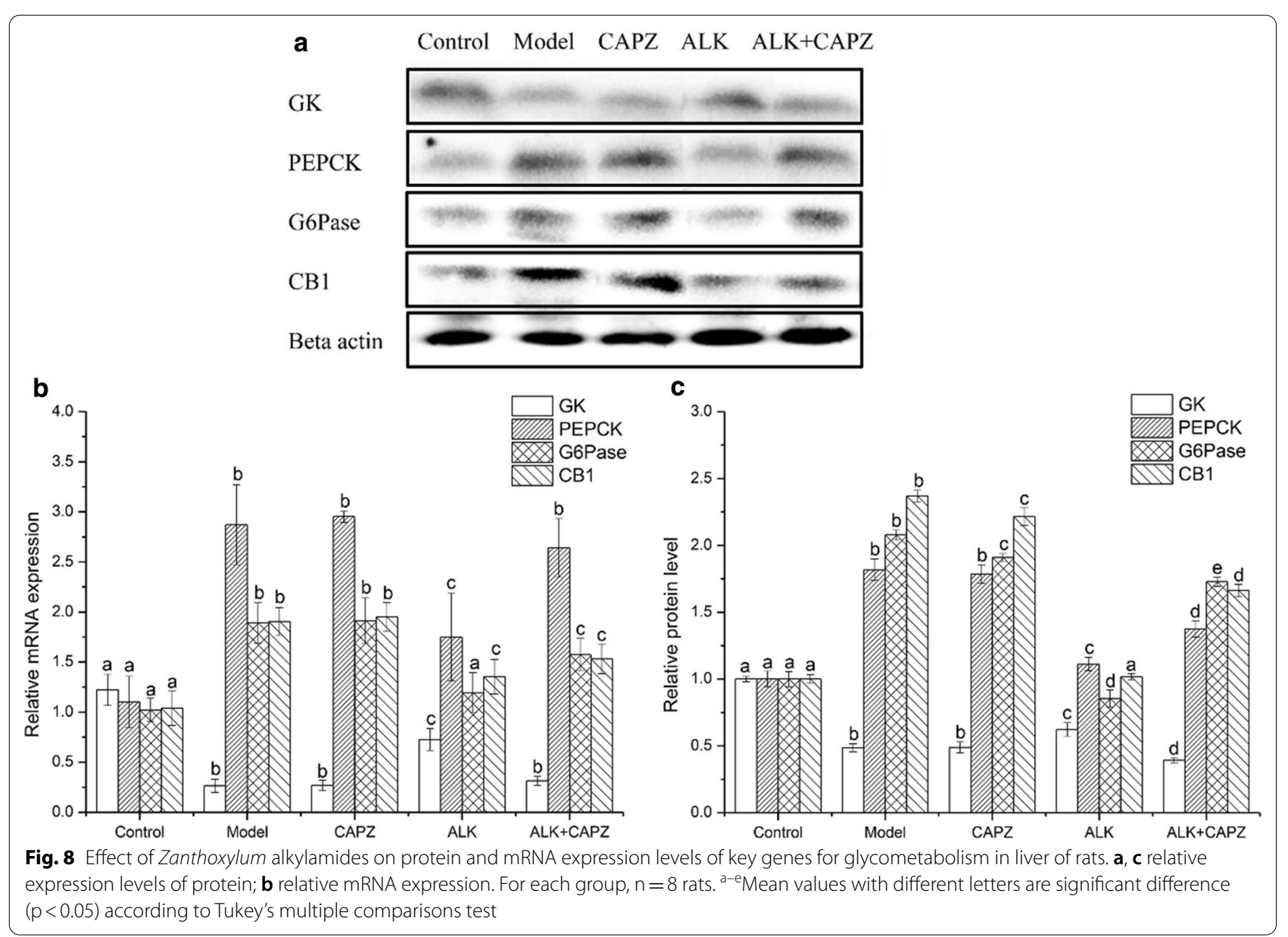

respectively $(\mathrm{P}<0.05)$. Compared with the ALK group, the expression of PEPCK in the rat liver of CAPZ and ALK + CAPZ groups increased significantly $(\mathrm{P}<0.05)$.

Compared with the control group, the expression of G6Pase mRNA and protein in the liver of the model group increased significantly by $83.50 \%$ and $107.82 \%$ respectively $(\mathrm{P}<0.05)$ as shown in Fig. 8 . Compared with the model group, the relative mRNA expression of G6Pase in CAPZ group had no significant difference. However, the expression of G6Pase in the ALK group and ALK + CAPZ group significantly decreased. Compared with the ALK group, the expression of G6Pase mRNA and protein in the rat liver of CAPZ group increased by $59.17 \%$ and $123.42 \%$ respectively. The expression of G6Pase mRNA and protein in ALK + CAPZ group increased by $30.83 \%$ and $102.11 \%$ respectively $(\mathrm{P}<0.05)$.

Compared with the control group, the expression of $\mathrm{CB} 1 \mathrm{mRNA}$ and protein in the liver of the model group increased by $81.90 \%$ and $136.95 \%$ respectively $(\mathrm{P}<0.05)$ (Fig. 8). Compared with the model group, the expression of CB1 in CAPZ group had no significant difference. However, the expression of CB1 in the ALK group and ALK + CAPZ group significantly decreased. In the ALK group, the expression of CB1 mRNA and protein in the liver of rats decreased by $28.80 \%$ and $57.09 \%$ respectively $(\mathrm{P}<0.05)$. Compared with the ALK group, the expression of $\mathrm{CB} 1$ in the CAPZ group increased significantly $(\mathrm{P}<0.05)$.

\section{Effects on the expression of insulin secretion related genes and protein in pancreas}

The effects of TRPV1 receptor antagonist and Zanthoxylum alkylamides on the expression of PDX-1 mRNA and protein in the pancreas of diabetic rats are shown in Fig. 9. Compared with the control group, the relative mRNA expression of PDX-1 in the model group decreased by $88.14 \%$, and the relative protein level 


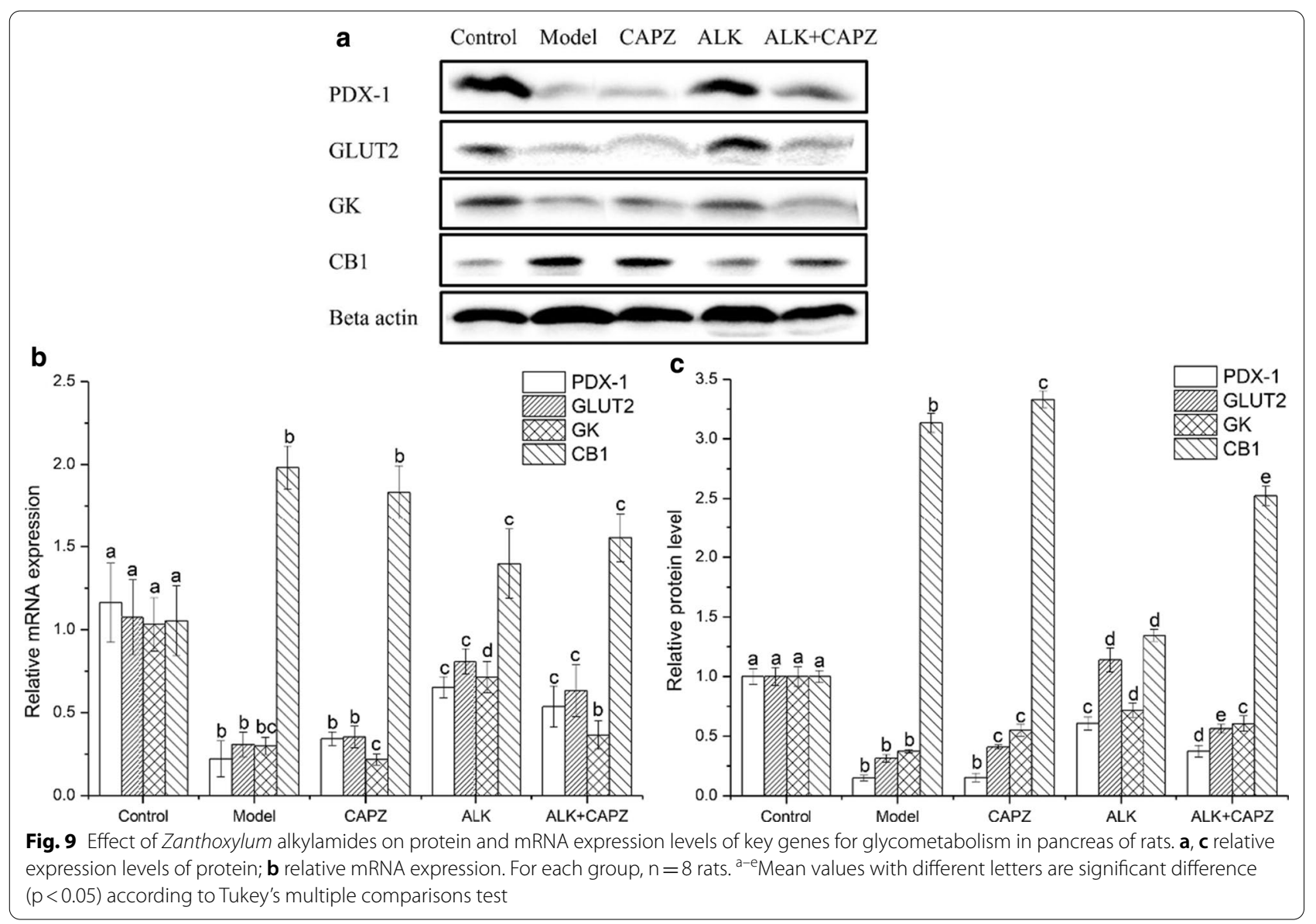

decreased by $85.07 \%(\mathrm{P}<0.05)$. Compared with the model group, after the rats were administrated for 28 days, the expression of PDX-1 in the pancreas of rats in each treatment group had changed. The expression of PDX-1 mRNA and protein in the pancreas of rats in ALK group significantly increased by $335.71 \%$ and $306.32 \%$ respectively $(\mathrm{P}<0.05)$. Compared with the ALK group, the expression of PDX-1 mRNA and protein in CAPZ group decreased significantly $(\mathrm{P}<0.05)$. However, the relative mRNA expression of PDX-1 in ALK + CAPZ group had no significant difference, whereas the relative protein level of PDX-1 in the ALK + CAPZ group decreased significantly.

As can be seen from Fig. 9, compared with the control group, the expression of GLUT2 mRNA and protein in the pancreas of rats in the model group decreased significantly by $71.03 \%$ and $68.55 \%$ respectively $(\mathrm{P}<0.05)$. Compared with the model group, the expression of GLUT2 mRNA and protein in the pancreas of rats in different administration groups increased to different degrees. The expression of GLUT2 mRNA and protein in the pancreas of rats in the ALK group significantly increased by $158.06 \%$ and $262.36 \%$ respectively
$(\mathrm{P}<0.05)$. Compared with the ALK group, the expression of GLUT2 mRNA and protein in pancreas of CAPZ group decreased by $56.25 \%$ and $64.15 \%$ respectively. The expression of GLUT2 mRNA and protein in the pancreas of ALK + CAPZ group decreased by $21.25 \%$ and $50.47 \%$ respectively $(\mathrm{P}<0.05)$.

As shown in Fig. 9, compared with the control group, the relative mRNA expression of GK in the model group significantly decreased by $70.19 \%$, and the relative protein level decreased by $62.64 \% \quad(\mathrm{P}<0.05)$. Compared with the model group, the relative mRNA expression of GK in the ALK + CAPZ group had no significant difference. However, the expression of GK mRNA and protein in the ALK group increased significantly by $132.26 \%$ and $92.14 \%$ respectively $(\mathrm{P}<0.05)$. Compared with the ALK group, the expression of GK in the CAPZ group and ALK + CAPZ group significantly decreased $(\mathrm{P}<0.05)$.

Compared with the control group, the relative mRNA expression of CB1 in the model group increased by $87.62 \%$, and the relative protein level increased by 213.49\% $(\mathrm{P}<0.05)$ (Fig. 9). Compared with the model group, after the rats were given administration for 
28 days, the relative mRNA expression of CB1 in different groups decreased to different degrees. The expression of CB1 mRNA and protein in the pancreas of rats in the ALK group decreased significantly by $28.93 \%$ and $57.10 \%$ respectively $(\mathrm{P}<0.05)$. Compared with the ALK group, the expression of CB1 mRNA and protein in pancreas of CAPZ group increased by $30.71 \%$ and $147.71 \%$ respectively. The expression of CB1 mRNA and protein in pancreas of ALK + CAPZ group increased by $10.71 \%$ and $87.63 \%$ respectively $(\mathrm{P}<0.05)$.

\section{Discussion}

As far as we know, Capsazepine is an effective antagonist at TRPV1 receptor from rat, human and guinea pig [29]. By studying the effect of intraperitoneal injection of capsazepine, given Zanthoxylum alkylamides by gavage or cotreatment of Zanthoxylum alkylamides and capsazepine on diabetic rats glucose metabolism induced by STZ, this experiment found that intraperitoneal injection of capsazepine had no significant effect on the fasting plasma glucose, oral glucose tolerance, plasma insulin level and the content of glycogen in liver and muscle. However, Zanthoxylum alkylamides can significantly decrease fasting blood glucose, improve oral glucose tolerance and increase plasma insulin and the level of liver glycogen in diabetic rats, thus improving the disorder of glucose metabolism in the diabetic rats. Moreover, the cotreatment of Zanthoxylum alkylamides and capsazepine significantly decreased the improving effect of $\mathrm{Zan}$ thoxylum alkylamides on glucose metabolism disorder in the diabetic rats. These results demonstrate that TRPV1 receptor might be involved in the regulation of Zanthoxylum alkylamides on glucose metabolism disorders.

In order to confirm the role of TRPV1 receptor in the hypoglycemic process of Zanthoxylum alkylamides and combined with previous research results [23], we compared the effect of Zanthoxylum alkylamides and the cotreatment of Zanthoxylum alkylamides and capsazepine on the expression of genes and protein related to liver glucose metabolism and the secretion of pancreas insulin in rats. Liver gluconeogenesis and glycolysis were the main approaches to maintain glucose homeostasis [30]. PEPCK, G6Pase and GK played important roles in liver gluconeogenesis and glycolysis [31,32]. The previous research results show that Zanthoxylum alkylamides could significantly decrease the expression of PEPCK and G6Pase in the liver and significantly increase the expression of GK, showing a certain dose effect [23]. This study also found that Zanthoxylum alkylamides significantly changes the expression of PEPCK, G6Pase and GK (Fig. 8), promoted the synthesis of liver glycogen and inhibited the output of liver glucose (Fig. 7). But the changes of the expression of PEPCK, G6Pase and GK caused by Zanthoxylum alkylamides in rat liver were significantly weakened by TRPV1 receptor antagonist capsazepine. In addition, the lack of insulin secretion was an important characteristic of Type 1 diabetes. Zanthoxylum alkylamides can increase the level of plasma insulin (Fig. 6) and regulate the expression of PDX-1, GLUT 2 and GK mRNA and protein in the pancreas of rats. PDX-1 is the key transcription factor of GLUT2 and GK, which can increase insulin secretion through up-regulation of GK and GLUT2 mRNA expression [33]. After TRPV1 activity was inhibited by capsazepine, the plasma insulin level of rats decreased significantly, and the expression of PDX-1, GLUT 2 and GK in the pancreas of rats also decreased. Studies have shown that activating TRPV1 receptors can increase intracellular calcium flow, thereby increasing the level of glucagon-like peptide (GLP)-1 and insulin in plasma, promoting glucose utilization, and improving glucose metabolism disorder in diabetic rats, but after human knockout TRPV1 genes, this effect disappeared [34]. Studies by Fagelskiold and his team have also confirmed that activating TRPV1 receptors can promote insulin secretion in INS-1E cells, but this effect was significantly weakened after their activity was inhibited by capsazepine [35]. According to the existing literature reports and the above results, it can be concluded that TRPV1 receptor was involved in the regulation of the expression of genes related to glucose metabolism and insulin secretion by Zanthoxylum alkylamides.

TRPV1 receptor distributed in body widely, it was first found in sensory nerves and could mediate the response of pain [36]. Later, it was found that TRPV1 receptor was also expressed in many non-nerve tissues closely related to glucose metabolism, such as gastrointestinal epithelium, liver, fat and pancreas [37]. As a kind of non-selective cation channel, the activation of TRPV1 can lead to the increase of intracellular calcium ion concentration, thereby affecting the expression of a variety of intracellular genes related to glucose and insulin secretion. Intracellular calcium ions had a variety of physiological functions and participated in the regulation of various cellular functions as a kind of messenger molecule [38]. Therefore, whether TRPV1 receptor functioned through intracellular calcium ions in Zanthoxylum alkylamides, regulating blood glucose metabolism in diabetic rats remains to be further elaborated. A study conducted by Koo showed that the hydroxy- $\alpha$-sanshool could activate TRPV1 and TRPA1 channels. They concluded that the hydroxy- $\alpha$-sanshool causes tingling or possibly nociceptive behavior, then a pungent tingling sensation by activating TRPV1 and TRPA1 in sensory neurons. Moreover, eventhough a major functional role of TRPV1 is the mediation of nociception, it is highly likely that TRPV1 also mediates other sensations [39]. Thus, the 
Zanthoxylum alkylamides could cause tingling or possibly nociceptive behavior, then a pungent tingling sensation by activating TRPV1 in sensory neuron, regulated the expression of related genes.

It was notable that the endogenous cannabinoid system was closely related to body appetite, energy metabolism and insulin secretion [40]. As important members of the endogenous cannabinoid system, while CB1 cannabinoid receptors couple to focal adhesion kinase could control insulin release [41]. The study of Katarzyna has shown that through the combined influence of CB1 and TRPV1 receptor, endogenous cannabinoids affected the development of pancreas and the differentiation of cells [42]. This study showed that Zanthoxylum alkylamides could significantly decrease the expression of CB1 mRNA and protein in liver and pancreas, and this effect was weakened by TRPV1 receptor competitive inhibitor capsazepine. Therefore, the interaction and mechanism of CB1 and TRPV1 in the regulation of body glucose metabolism by Zanthoxylum alkylamides deserve our attention.

To sum up, Zanthoxylum alkylamides could ameliorate the glucose metabolism disorder in diabetic rats. Moreover, the TRPV1 receptor could participate in regulating the expressions of genes and proteins related to glucose metabolism and insulin secretion in the liver and pancreas, and plays a role in the hypoglycemic process of Zanthoxylum alkylamides.

\section{Conclusions}

By regulating the expression of genes related to hepatic glucose metabolism and pancreas insulin secretion, $\mathrm{Zan}$ thoxylum alkylamides decreased the level of the fasting blood glucose and serum fructosamine in diabetic rats induced by STZ, improved oral glucose tolerance, increased plasma insulin and liver glycogen content, thus improving the glucose metabolism disorders in diabetic rats. Further studies demonstrated that TRPV1 receptor could participate in regulating the expression of genes related to liver glucose metabolism and pancreatic insulin secretion in rats, plays a role in the hypoglycemic process of Zanthoxylum alkylamides.

\section{Acknowledgements}

This research was supported by the National Natural Science Foundation of China (31171679).

\section{Authors' contributions}

RW and YY performed the experiments and wrote the manuscript. $X L$ designed and supervised the study. All authors read and approved the final manuscript.

\section{Funding}

This research was supported by the National Natural Science Foundation of China (31171679).

\section{Availability of data and materials}

Datasets used and/or analyzed during the current study that are not included in the manuscript are available from the corresponding author on reasonable request.

\section{Competing interests}

The authors declare that they have no competing interests.

\section{Author details \\ ${ }^{1}$ College of Food Science, Southwest University, Chongqing 400715, China. ${ }^{2}$ Chongqing Collaborative Innovation Center for Functional Food, Chong- qing University of Education, Chongqing 400067, China. ${ }^{3}$ College of Forestry and Life Sciences, Chongqing University of Arts and Sciences, Chong- qing 401331, China.}

Received: 28 July 2020 Accepted: 24 October 2020

Published online: 21 January 2021

\section{References}

1. Wong GY, Gavva NR (2009) Therapeutic potential of vanilloid receptor TRPV1 agonists and antagonists as analgesics: Recent advances and setbacks. Brain Res Rev 60:267-277

2. Rohacs T, Thyagarajan B, Lukacs V (2008) Phospholipase C mediated modulation of TRPV1 channels. Mol Neurobiol 37:153-163

3. Immke DC, Gavva NR (2006) The TRPV1 receptor and nociception. Semin Cell Dev Biol 17:582-591

4. Gunthorpe MJ, Szallasi A (2008) Peripheral TRPV1 receptors as targets for drug development: new molecules and mechanisms. Curr Pharm Design 14:32-41

5. Premkumar LS, Bishnoi M (2011) Disease-related changes in TRPV1 expression and its implications for drug development. Curr Top Med Chem 11:2192-2209

6. Zsombok A (2013) Vanilloid receptors-do they have a role in whole body metabolism? Evidence from TRPV1. J Diabetes Complicat 27:287-292

7. Liddle RA (2007) The role of transient receptor potential vanilloid 1 (TRPV1) channels in pancreatitis. Bba-Mol basis Dis 1772:869-878

8. Diaz-Garcia CM, Morales-Lazaro SL, Sanchez-Soto C, Velasco M, Rosenbaum T, Hiriart M (2014) Role for the TRPV1 channel in insulin secretion from pancreatic beta cells. J Membrane Biol 247:479-491

9. Akiba Y, Kato S, Katsube K, Nakamura M, Takeuchi K, Ishii H, Hibi T (2004) Transient receptor potential vanilloid subfamily 1 expressed in pancreatic islet beta cells modulates insulin secretion in rats. Biochem Bioph Res Co 321:219-225

10. Suri A, Szallasi A (2008) The emerging role of TRPV1 in diabetes and obesity. Trends Pharmacol Sci 29:29-36

11. Xia LA, You JM, Li GL, Sun ZW, Suo YR (2011) Compositional and antioxidant activity analysis of Zanthoxy/um bungeanum seed oil obtained by supercritical $\mathrm{CO}_{2}$ fluid extraction. J Am Oil Chem Soc 88:23-32

12. Ji Y, Li SM, Ho CT (2019) Chemical composition, sensory properties and application of Sichuan pepper (Zanthoxylum genus). Food Sci Hum Well 8:115-125

13. Zhu BQ, Yang JF, Song TT, Li XF, Guo T, Wang LL, Wang Y, Chang J (2020) Chemical Constituents of Zanthoxylum bungeanum. Chem Nat Compd $56: 25$

14. Artaria C, Maramaldi G, Bonfigli A, Rigano L, Appendino G (2011) Lifting properties of the alkamide fraction from the fruit husks of Zanthoxylum bungeanum. Int J Cosmetic Sci 33:328-333

15. Chen KW, Zhang FS, Kan JQ (2012) Characterization of chlorophyll breakdown in green prickleyashes (Zanthoxylum schinifolium Zucc.) during slow drying. Eur Food Res Technol 234:1023-1031

16. Diao WR, Hu QP, Feng SS, Li WQ, Xu JG (2013) Chemical composition and antibacterial activity of the essential oil from green Huajiao (Zanthoxy/um schinifolium) against selected foodborne pathogens. J Agr Food Chem 61:6044-6049

17. Zhao ZF, Zhu RX, Zhong K, He Q, Luo AM, Gao H (2013) Characterization and Comparison of the Pungent Components in Commercial Zanthoxylum bungeanum Oil and Zanthoxylum schinifolium Oil. J Food Sci 78:C1516-C1522 
18. Hatano T, Inada K, Ogawa T, Ito H, Yoshida T (2004) Aliphatic acid amides of the fruits of Zanthoxylum piperitum. Phytochemistry 65:2599-2604

19. Mizutani K, Fukunaga Y, Tanaka O, Takasugi N, Saruwatari Y, Fuwa T, Yamauchi T, Wang J, Jia MR, Li FY, Ling YK (1988) Amides from Huajiao, pericarps of Zanthoxylum-Bungeanum Maxim. Chem Pharm Bull 36:2362-2365

20. Xiong QB, Shi DW, Yamamoto H, Mizuno M (1997) Alkylamides from pericarps of Zanthoxylum bungeanum. Phytochemistry 46:1123-1126

21. Zhang MM, Wang JL, Zhu L, LiT, Jiang WD, Zhou J, Peng W, Wu CJ (2017) Zanthoxylum bungeanum Maxim. (Rutaceae): a systematic review of its traditional uses, botany, phytochemistry, pharmacology, pharmacokinetics, and toxicology. Int J Mol Sci 18:2172

22. Tsunozaki M, Lennertz RC, Vilceanu D, Katta S, Stucky CL, Bautista DM (2013) A "toothache tree" alkylamide inhibits A delta mechanonociceptors to alleviate mechanical pain. J Physiol-London 591:3325-3340

23. You YM, Ren T, Zhang SQ, Shirima GG, Cheng YJ, Liu X (2015) Hypoglycemic effects of Zanthoxylum alkylamides by enhancing glucose metabolism and ameliorating pancreatic dysfunction in streptozotocin-induced diabetic rats. Food Funct 6:3144-3154

24. Bryant BP, Mezine I (1999) Alkylamides that produce tingling paresthesia activate tactile and thermal trigeminal neurons. Brain Res 842:452-460

25. Murata P, Hayakawa T, Satoh K, Kase Y, Ishige A, Sasaki H (2001) Effects of Dai-kenchu-to, a herbal medicine, on uterine and intestinal motility. Phytother Res 15:302-306

26. Ren TY, Zhu YP, Xia XJ, Ding YB, Guo J, Kan JQ (2017) Zanthoxylum alkylamides ameliorate protein metabolism disorder in STZ-induced diabetic rats. J Mol Endocrinol 58:113-125

27. Solinas M, Tanda G, Justinova Z, Wertheim CE, Yasar S, Piomelli D, Vadive SK, Makriyannis A, Goldberg SR (2007) The endogenous cannabinoid anandamide produces delta-9-tetrahydrocannabinol-like discriminative and neurochemical effects that are enhanced by inhibition of fatty acid amide hydrolase but not by inhibition of anandamide transport. J Pharmacol Exp Ther 321:370-380

28. Talbot S, Dias JP, Lahjouji K, Bogo MR, Campos MM, Gaudreau P, Couture R (2012) Activation of TRPV1 by capsaicin induces functional Kinin B-1 receptor in rat spinal cord microglia. J Neuroinflamm 9:16

29. Phillips E, Reeve A, Bevan S, Mclntyre P (2004) Identification of speciesspecific determinants of the action of the antagonist capsazepine and the agonist PPAHV on TRPV1. J BIOL CHEM 279:17165-17172

30. Xiong XW, Tao RY, DePinho RA, Dong XC (2013) Deletion of hepatic FoxO1/3/4 genes in mice significantly impacts on glucose metabolism through downregulation of gluconeogenesis and upregulation of glycolysis. PLOS ONE 8:e74340

31. Noguchi R, Kubota H, Yugi K, Toyoshima Y, Komori Y, Soga T, Kuroda S (2013) The selective control of glycolysis, gluconeogenesis and glycogenesis by temporal insulin patterns. Mol Syst Biol 9:664
32. Lee JS, Choi MS, Seo Kl, Lee J, Lee HI, Lee JH, Kim MJ, Lee MK (2014) Platycodi radix saponin inhibits alpha-glucosidase in vitro and modulates hepatic glucose-regulating enzyme activities in C57BL/KsJ-db/db mice. Arch Pharm Res 37:773-782

33. Zhang SQ, You YM, LIU J, Qin XL, Liu X, (2018) Hypoglycaemic effect of capsaicinoids via elevation of insulin level and inhibition of glucose absorption in streptozotocin-induced diabetic rats. J FUNCT FOODS 51:94-103

34. Wang PJ, Yan ZC, Zhong J, Chen J, Ni YX, Li L, Ma LQ, Zhao ZG, Liu DY, Zhu ZM (2012) Transient receptor potential vanilloid 1 activation enhances gut glucagon-like peptide-1 secretion and improves glucose homeostasis. Diabetes 61:2155-2165

35. Fagelskiold AJ, Kannisto K, Bostrom A, Hadrovic B, Farre C, Eweida M, Wester K, Islam MS (2012) Insulin-secreting INS-1E cells express functional TRPV1 channels. Islets 4:8

36. Caterina MJ, Schumacher MA, Tominaga M, Rosen TA, Levine JD, Julius D (1997) The capsaicin receptor: a heat-activated ion channel in the pain pathway. Nature 389:816-824

37. Chen J, Li L, Li YS, Liang X, Sun QQ, Yu H, Zhong J, Ni YX, Chen J, Zhao ZG, Gao P, Wang B, Liu DY, Zhu ZM, Yan ZC (2015) Activation of TRPV1 channel by dietary capsaicin improves visceral fat remodeling through connexin43-mediated Ca2+ Influx. Cardiovasc Diabetol 14:22

38. Ramachandran KV, Hennessey JA, Barnett AS, Yin XH, Stadt HA, Foster E, Shah RA, Yazawa M, Dolmetsch RE, Kirby ML, Pitt GS (2013) Calcium Influx through L-Type Ca (V) $1.2 \mathrm{Ca}^{2+}$ channels regulates mandibular development. J CLIN INVEST J Clin Invest 123:1638-1646

39. Koo JY, Jang Y, Cho H, Lee CH, Jang KH, Chang YH, Shin J, Oh U (2007) Hydroxy-alpha-sanshool activates TRPV1 and TRPA 1 in sensory neurons. EUR J NEUROSCI 26:1139-1147

40. Li C, Jones PM, Persaud SJ (2011) Role of the endocannabinoid system in food intake, energy homeostasis and regulation of the endocrine pancreas. Pharmacol Therapeut 129:307-320

41. Malenczyk K, Jazurek M, Keimpema E, Silvestri C, Janikiewicz J, Mackie K, Di MV, Redowicz MJ, Harkany T, Dobrzyn A (2013) Cb1 cannabinoid receptors couple to focal adhesion kinase to control insulin release. J Biol Chem 288:32685-32699

42. Malenczyk K, Keimpema E, Piscitelli F, Calvigioni D, Bjorklund P, Mackie K, Di MV, Hokfelt TGM, Dobrzyn A, Harkany T (2015) Fetal endocannabinoids orchestrate the organization of pancreatic islet microarchitecture. P Natl Acad Sci USA 112:E6185-E6194

\section{Publisher's Note}

Springer Nature remains neutral with regard to jurisdictional claims in published maps and institutional affiliations.

\section{Submit your manuscript to a SpringerOpen ${ }^{\circ}$ journal and benefit from:}

- Convenient online submission

- Rigorous peer review

- Open access: articles freely available online

- High visibility within the field

- Retaining the copyright to your article

Submit your next manuscript at springeropen.com 